\title{
Effective Use in Livestock Feeds of Mouldy and Weather-damaged Grain Containing Mycotoxins-Case Histories and Economic Assessments Pertaining to Pig and Poultry Industries of Queensland
}

\author{
Barry J. Blaney and Kevin C. Williams \\ Queensland Department of Primary Industries, \\ Animal Research Institute, Yeerongpilly, Qld 4105.
}

\begin{abstract}
Mould growth in field crops or stored grain reduces starch and lipid content, with consequent increases in fibre, and an overall reduction in digestible energy; palatability is often adversely affected. If these factors are allowed for, and mycotoxin concentrations are low, there are sound economic reasons for using this cheaper grain.

Mycotoxins are common in stock feed but their effects on animal productivity are usually slight because either the concentration is too low or the animal is tolerant to the toxin. In Australia, aflatoxins occur in peanut by-products and in maize and sorghum if the grain is moist when stored. Zearalenone is found in maize and in sorghum and wheat in wetter regions. Nivalenol and deoxynivalenol are found in maize and wheat but at concentrations that rarely affect pigs, with chickens and cattle being even more tolerant. Other mycotoxins including cyclopiazonic acid, T-2 toxin, cytochalasins and tenuazonic acid are produced by Australian fungi in culture but are not found to be significant grain contaminants.

Extremely mouldy sorghum containing Alternaria and Fusarium mycotoxins decreased feed conversion in pigs and chickens by up to $14 \%$. However, F. moniliforme- and Diplodia maydis-infected maize produced only slight reductions in feed intake by pigs and Ustilagoinfected barley produced no ill effects. Use of these grains would substantially increase profits if the grain can be purchased cheaply.
\end{abstract}

\section{Introduction}

Considerable quantities of mouldy and weather-damaged grain are available each year for animal feed. Weather-damage to the Australian wheat crop is usually about $8 \%$ in 'typical' years but may be as high as $20 \%$ (about $4 \times 10^{6}$ tonnes) in a 'bad' year such as occurred with the 1983/84 harvest (Davidson 1984). Summer grain crops such as sorghum and maize are particularly vulnerable to rain damage at harvest time. This results in germination and mould invasion of the grain.

'Weathering' refers to any deterioration in the appearance of the grain caused by climatic influences on the crop. It describes conditions such as shrunken and pinched grain following drought or soil fertility stress, all fungal attacks in the field, and premature germination of the grain (sprouted, shot, sprung) caused by wet or humid weather at the time of harvest. Mould growth also occurs when grain either is stored having a high moisture content or suffers water damage during post-harvest storage. As mould damage is 
often associated with weathered grain, these conditions should be discussed together.

How mouldy and weathered grain is used for animal feed depends on the extent to which the nutritional content of the grain has been altered (for better or worse), whether the palatability of the grain has been affected and whether mycotoxins are present in concentrations sufficient to affect animal performance.

In this paper, we discuss methods that allow these effects to be assessed using situations known to occur in northern Australia as examples. The economic consequences of use of certain types of mouldy grain for pig and poultry production are also analysed.

\section{Effects on Nutrient Content}

Many processes are involved with weathering and mould-damage which affect the chemical content and feeding value of the grain. Included are conditions such as shrunken and pinched grain resulting from the effects of drought on the crop, premature germination of the grain caused by wet or humid weather at time of harvest and all fungal attacks in the field including rusts, smuts, rots, scabs, etc. For convenience, these processes and their effects on nutritive quality will be discussed separately although, in practice, such a clear distinction is seldom possible.

\section{Pinched and Shrunken Grain}

Crops that have suffered some deprivation of water or nutrients (perhaps induced by fungal attack on the translocation system) during growth, result in pinched and shrunken grain. Consequently, there is a reduction in starch accumulation and a corresponding increase in hull and fibrous portions (Taverner et al. 1975; Moir and Connor 1977; Salmon and O'Neil 1977; Batterham et al. 1980; Taverner and Farrell 1981); protein and lysine content are usually higher in absolute terms but less available for monogastric animals because of a predominance of the gluten proteins (McDermott and Pace 1960; Deyoe and Shellenberger 1965; Eggum 1977).

\section{Shot and Sprung Grain}

Premature sprouting is often involved with weather-damaged grains. Peer and Leeson (1985a, 1985b) followed the changes taking place when barley was hydroponically germinated under light. Over seven days, weights of dry matter and starch decreased linearly with time, while crude fibre increased quadratically. Crude protein decreased over the first six days but then appeared to increase. By using cockerels, the metabolizable energy (ME) of sprouted barley measured on the day of sprouting was 30\% higher than unsprouted barley. The ME then decreased linearly with sprouting time so that, by day 7 , sprouted barley had only $58 \%$ as much $\mathrm{ME}$ as the unsprouted grain. At day 3 , sprouted barley was equivalent to unsprouted grain. In pigs, the digestible energy (DE) of day 4 sprouted barley was only about $84 \%$ of the unsprouted grain. These findings indicate that the nutritive value of sprouted grain changes greatly with time, being superior to unsprouted grain in the first 
day or two of germination but deteriorating rapidly thereafter. Field sprouted grain, in which the root radicle is visible only as a white tip, can be equated to day 1 sprouts. Where both root and shoot are visible, germination has been in progress for at least three days.

\section{Mould-damaged Grain}

Mould infection of the grain can reduce its nutritive value for monogastrics through the removal of storage starch and the hydrolysis of protein (Castor and Frederiksen 1981). Losses in lipid content due to fungal lipases also occur (Bartov et al. 1982; Mannion et al. 1987). These are likely to result in some lowering of the nutritive value of high lipid grains such as maize. Consequently, the amount of fibre in the grain will increase relative to the decline in starch, protein components and lipid, sometimes leading to reductions in DE and ME content (Taverner et al. 1975; Batterham et al. 1980; Mannion et al. 1987). However, Williams et al. (1986) found DE to be only slightly affected in several batches of severely weather-damaged sorghum. Where mould invasion is slight, some improvement in nutritive value may occur as a result of starch hydrolysis similar to that seen in early germination. Deteriorated grain will be lighter in weight, discoloured and darkened if mould invasion is extensive, and the endosperm is likely to have a chalky appearance due to the partial hydrolysis of the nutrient stores (Christensen and Kaufman 1965). In such grain, fibre values are invariably higher and protein levels may also be increased.

Table 1. Effect of bulk density of common grains on digestible energy content for pigs

Compilation of data from Taverner et al. (1975), Batterham et al. (1980) and Williams and Mcintosh (1986)

\begin{tabular}{ccccc}
\hline $\begin{array}{c}\text { Density } \\
\left(\mathrm{kg} \mathrm{hL}^{-1}\right)\end{array}$ & Barley & $\begin{array}{c}\text { Digestible energy }\left(\mathrm{MJ} \mathrm{kg}^{-1} \text { as fed }\right) \\
\text { Wheat }\end{array}$ & Sorghum & Maize \\
\hline 50 & $11 \cdot 8$ & $12 \cdot 8$ & $13 \cdot 1$ & \\
55 & $12 \cdot 2$ & $13 \cdot 2$ & $13 \cdot 5$ & \\
60 & $12 \cdot 6$ & $13 \cdot 6$ & $13 \cdot 8$ & \\
65 & $12 \cdot 9$ & $13 \cdot 9$ & $14 \cdot 0$ & \\
70 & $13 \cdot 0$ & $14 \cdot 1$ & $14 \cdot 2$ & $14 \cdot 7$ \\
$75+$ & $14 \cdot 3$ & $14 \cdot 3$ & $14 \cdot 2$ & \\
Fair average & $12 \cdot 9$ & $14 \cdot 2$ & $14 \cdot 2$ & $14 \cdot 7$ \\
quality & & & & \\
\hline
\end{tabular}

Bulk density is a simple measurement which can be quickly made on-farm to assess semi-quantitatively DE content. This relationship is given in Table 1. A more precise estimate of $\mathrm{DE}$ can be obtained using prediction equations based on chemical rather than physical attributes. Usually some form of fibre measurement is required (Batterham et al. 1980; Taverner and Farrell 1981).

With pigs and poultry, the nutritional deficiencies of weather-damaged grains can be compensated for during dietary formation, mainly by increasing the ME with lipids (Bartov 1983; Mannion et al. 1987). Naturally, these changes are of much less significance in ruminant nutrition than with pigs and poultry. In ruminants, the digestibility of fibre from the grain cell wall is about $50 \%$, 
much greater than in monogastrics, while moderate reductions in lipids and amino acids are less important compared with total nitrogen. Consequently, very badly damaged grain can be used as ruminant feed provided that it is palatable and mycotoxin concentrations are not harmful.

\section{Effects of Palatability}

Damaged grain that has undergone fungal invasion may exhibit 'off' aromas and flavours and be unpalatable to pigs which exhibit strong taste preferences when food is freely available (Baldwin 1976). However, when there is no choice, the pig will eat unpalatable food out of hunger and may even become accustomed to the taste if fed over a long period. Any depression in food intake due to unpalatability of the diet is undesirable and this is particularly so for pigs less than $50 \mathrm{~kg}$ liveweight where maximum growth rate is sought. With chickens, the appearance of the food is more important in deciding what is eaten (Rogers 1985; Adret-Hausberger and Cumming 1985). However, some extremely bitter feed ingredients such as the galactomannan gums of guar meal (Grammer et al. 1983) have caused pronounced reductions in feed intakes, particularly when heated during pelleting. Horses are also sensitive to 'off aromas'. Cattle and sheep are less sensitive to aroma but may reject some mouldy feeds, particularly if dusty.

There are many other causes of poor palatability, such as the presence of certain weed seeds (e.g. Sesbania sp.; Williams and Daniels 1985) which are common in weather-damaged grains, rancidity (Francis and Wood 1982) and certain naturally occurring toxins such as tannins (Connor et al. 1969; Mangan 1988; Griffiths 1989) and alkaloids (Erickson 1988). Methods used to overcome poor palatability include the use of sugar, molasses, flavour enhancers and ingredients such as peanut and coconut meals (Baldwin 1976; Baidoo and Aherne 1986). The addition of oil also reduces dust, another contributor to reduced feed intakes.

It is important to distinguish between palatability as such, and other effects causing reduced feed intakes. In intensively fed animals, decreased feed intake is usually the first sign of chronic intoxication, e.g. by aflatoxins (Allcroft 1969). Other mycotoxins such as trichothecenes have specific systemic effects causing nausea and emesis which are not overcome by flavour-additives (Forsyth et al. 1977; Williams and Blaney, unpublished data).

\section{Mycotoxins}

Mycotoxins frequently occur in animal feeds. In most cases, no adverse effects are noticed either because the mycotoxins are not in sufficiently high concentration, the particular animal species is not susceptible to the mycotoxin, the mycotoxin is not fed for a long enough period of time or a good balance of nutrients allows the animal to withstand the toxicity.

In a few cases, fungi are sufficiently prevalent in a given grain crop or storage situation to produce mycotoxins in sufficient concentrations to cause substantial animal production losses through deaths or impaired growth. To date in Australia, mycotoxins in this category include aflatoxins, zearalenone and deoxynivalenol occurring mainly in grains, and phomopsins, sporidesmin and ergot alkaloids occurring mainly in forages. 
Table 2. Mycotoxins known to occur in Australia, fungal sources and prevalence

\begin{tabular}{|c|c|c|c|}
\hline Mycotoxin & Fungal source & Prevalence & References \\
\hline Aflatoxins & $\begin{array}{l}\text { Aspergillus } \\
\text { flavus } \\
\text { A. parasiticus }\end{array}$ & $\begin{array}{l}\text { Common in peanuts; } \\
\text { uncommon in sorghum } \\
\text { and maize; occasionally } \\
\text { in other grains, oilseeds } \\
\text { and mixed feeds }\end{array}$ & $\begin{array}{l}\text { Blaney (1984, 1985); } \\
\text { Bryden et al. }(1975,1980) \text {; } \\
\text { Connole et al. (1981) }\end{array}$ \\
\hline $\begin{array}{l}\text { Cyclopiazonic } \\
\text { acid }\end{array}$ & A. flavus & $\begin{array}{l}\text { Unknown; produced } \\
\text { in culture }\end{array}$ & Blaney et al. (1989) \\
\hline Ochratoxin A & A. ochraceus & $\begin{array}{l}\text { Occasionally in maize } \\
\text { and mixed feeds }\end{array}$ & $\begin{array}{l}\text { Connole et al. (1981); } \\
\text { Ketterer et al. (1982) }\end{array}$ \\
\hline Zearalenone & $\begin{array}{l}\text { Fusarium } \\
\text { graminearum }\end{array}$ & $\begin{array}{l}\text { Common in maize } \\
\text { and sorghum in wetter } \\
\text { regions; occasionally in } \\
\text { wheat and triticale }\end{array}$ & $\begin{array}{l}\text { Blaney et al. (1984a, } \\
1984 b, 1986,1987) \\
\text { Williams et al. (1986) }\end{array}$ \\
\hline Deoxynivalenol & $\begin{array}{l}\text { F. graminearum } \\
\text { Groups } 1 \text { and } 2\end{array}$ & $\begin{array}{l}\text { Occasionally in wheat } \\
\text { and triticale }\end{array}$ & $\begin{array}{l}\text { Blaney et al. (1987); } \\
\text { Moore et al. (1985); } \\
\text { Tobin (1988) }\end{array}$ \\
\hline $\begin{array}{l}\text { Nivalenol and } \\
\text { derivatives }\end{array}$ & $\begin{array}{l}\text { F. graminearum } \\
\text { Group } 2\end{array}$ & $\begin{array}{l}\text { Common in maize in } \\
\text { northern Queensland }\end{array}$ & $\begin{array}{l}\text { Blaney and Dodman } \\
\text { (1988, unpubl. data) }\end{array}$ \\
\hline $\begin{array}{l}\mathrm{T}-2 \text { and } \mathrm{HT}-2 \\
\text { toxins }\end{array}$ & Fusarium sp. & $\begin{array}{l}\text { Unknown; produced } \\
\text { in culture }\end{array}$ & $\begin{array}{l}\text { Blaney, Dodman, Tyler } \\
\text { and Moore (unpubl.) }\end{array}$ \\
\hline $\begin{array}{l}\text { Cytochalasins } \\
\mathrm{H} \text { and } \mathrm{J}\end{array}$ & $\begin{array}{l}\text { Phomopsis } \\
\text { longicolla }\end{array}$ & $\begin{array}{l}\text { Unknown; produced } \\
\text { in culture }\end{array}$ & Allen et al. (1989) \\
\hline Phomopsins & $\begin{array}{l}\text { P. lepto- } \\
\text { stromiformis }\end{array}$ & Common in lupins & $\begin{array}{l}\text { Wood and Petterson } \\
\text { (1986) }\end{array}$ \\
\hline Sporidesmin & $\begin{array}{l}\text { Pithomyces } \\
\text { chartarum }\end{array}$ & $\begin{array}{l}\text { Sporadic in pastures in } \\
\text { southern Australia }\end{array}$ & $\begin{array}{l}\text { Walsh (1966); } \\
\text { Gardiner and Nairn } \\
\quad(1962)\end{array}$ \\
\hline $\begin{array}{l}\text { Ergot } \\
\text { alkaloids }\end{array}$ & Claviceps spp. & $\begin{array}{l}\text { Mainly in pasture, } \\
\text { uncommon }\end{array}$ & $\begin{array}{l}\text { Connole and Johnston } \\
\text { (1967) }\end{array}$ \\
\hline Alternariols & $\begin{array}{l}\text { Alternaria } \\
\text { alternata }\end{array}$ & $\begin{array}{l}\text { Common in sorghum, } \\
\text { occasionally in wheat }\end{array}$ & $\begin{array}{l}\text { Bryden et al. }(1984) \\
\text { Blaney et al. }(1987) \\
\text { Williams et al. }(1986)\end{array}$ \\
\hline $\begin{array}{l}\text { Altertoxins, } \\
\text { Altenuene, } \\
\text { Tenuazonic } \\
\text { acid }\end{array}$ & A. alternata & $\begin{array}{l}\text { Unknown; produced } \\
\text { in culture }\end{array}$ & $\begin{array}{l}\text { S. Andrews } \\
\text { (pers. commun.) }\end{array}$ \\
\hline Penitrem A & $\begin{array}{l}\text { Penicillium } \\
\text { crustosum }\end{array}$ & Mouldy dog food & Hocking et al. (1988) \\
\hline Patulin & P. expansum & Apple juice & $\begin{array}{l}\text { G. Fazekas } \\
\text { (pers. commun.) }\end{array}$ \\
\hline Viriditoxin & $\begin{array}{l}\text { Paecilomyces } \\
\text { varioti }\end{array}$ & $\begin{array}{l}\text { Unknown, produced } \\
\text { in culture }\end{array}$ & Green et al. (1989) \\
\hline
\end{tabular}


In other cases, reduced growth rates or feed conversions caused directly by mycotoxins are hard to differentiate from those caused by reduced nutritional value. For example, Alternaria spp: are fairly common in grains and forage and their mycotoxins are suspected of contributing to poor animal performance but no acute poisoning has been identified. Several other mycotoxins are known to occur in Australia but their comparative importance in animal disease is yet to be clarified. The documented occurrence of mycotoxins in Australia is given in Table 2.

Even with the most important of these mycotoxins there are procedures to minimize their impact. Firstly, an assessment can be made of the situations in which a particular type of contamination occurs. Surveys of crops in different climatic regions can provide a basis for such an evaluation (Blaney 1981; Blaney et al. 1984b, 1986, 1987) when supported by information gathered over seasons by plant pathologists and agricultural advisers on the prevalence of a given fungus in a crop.

Secondly, rapid methods of physical evaluation can indicate the likelihood of mycotoxin contamination. Such tests involve the bright greenish-yellow fluorescence associated with Aspergillus spp. invasion and aflatoxin contamination (Blaney 1981), the characteristic reddish-purple discolouration of grain produced by some Fusarium spp. (Blaney et al. 1986, 1987) and the presence of ergots.

Thirdly, there is the accurate chemical assay for common mycotoxins. Only the use of the results of an accurate analysis can guide dilution to safe levels or distribute the mouldy grain between more or less susceptible animal species and classes or ages of animals. Other factors to be considered are possible immunosuppressant, teratogenic and abortifacient effects. While such effects are rare with mycotoxins, they may contra-indicate the use of mouldy grains for breeding animals. Furthermore, the possible presence of mycotoxin residues may indicate that a withdrawal period be observed for animals close to slaughter.

In the following sections, we concentrate on specific mycotoxins and fungal infections of grains occurring in tropical and subtropical Australia. Extensive surveys have been performed in this region for mycotoxins. Much of the information is relevant to other parts of Australia but it is possible that cooler regions may harbour a different range of grain quality problems that remain uninvestigated.

\section{Aflatoxins}

In northern Australia, aflatoxins are fairly common in the summer crops, peanuts, maize and sorghum (Blaney 1985), but not in the winter crops, wheat and barley, unless these are stored moist (Blaney 1986). High summer temperatures combined with irregular rainfall and insect damage are probably important factors in allowing Aspergillus flavus and $A$. parasiticus to invade summer crops in the field. However, aflatoxin concentrations in maize and sorghum before harvest are usually too low to affect animal production. By far the most important cause of aflatoxin problems is failure to dry the grains adequately before storage. Inexperience in the use of driers by farmers is a 
major factor. Cases of aflatoxicosis commonly occur from March to August, about 4 weeks after harvesting the grain, when there has been $2-3$ weeks for the fungus to develop, and the animals, usually pigs, have been fed for 1-2 weeks. The first sign noticed by the farmer is often a decreased feed intake usually about 2-3 days after the grain is first fed. However, onset of toxicity will depend on the amount of toxin present. Aflatoxins have caused problems in piggeries on the Darling Downs, the Burnett region and Central Queensland, involving mouldy bread, sorghum, peanut by-products and maize (Ketterer et al. 1982; Blaney, unpublished data). Cattle have also been poisoned on several occasions by peanut hay, screenings or meal (McKenzie et al. 1981; Blaney, unpublished data). The case histories indicate serious economic losses to individual farmers, even though the total number of cases is not large (we have observed 2-3 cases of sub-acute aflaxtoxicosis yearly from 1980-90). The losses result from deaths, reduced growth rate, poor feed conversion and carcass condemnation. We estimate that each case of sub-acute aflatoxicosis can cost up to $\$ 10000$ (1990 value). We consider that there could be a greater number of cases in which aflatoxicosis was not suspected, particularly if the only effect was a worsening of feed conversion.

Farmers wishing to utilize mouldy grain shown to contain aflatoxins should undertake a detailed risk assessment based on accurate aflatoxin analyses. Obviously mouldy pockets of grain should be discarded (having regard for human exposure) and the remainder dried, mixed and several representative samples taken for assay. The problem in setting acceptable levels for aflatoxins is that tolerances are obtained experimentally by using relatively small numbers of animals fed on well balanced diets. In the field, there can be a great variation in individual susceptibilities, confounded by stressors not present under experimental conditions. Subject to these limitations, we suggest in Table 3 the maximum aflatoxin Bl equivalent concentrations in pig feeds.

Table 3. Maximum aflatoxin B1 equivalent concentrations in pig feeds

\begin{tabular}{lc}
\hline \multicolumn{1}{c}{ Pig class } & Aflatoxin B1 equivalent $\left(\mathrm{mg} \mathrm{kg}^{-1}\right)^{\mathrm{A}}$ \\
\hline Weaners (less than $20 \mathrm{~kg}$ liveweight) & $<0 \cdot 02$ \\
Growers (20-50 kg liveweight) & $<0 \cdot 1$ \\
Finishers (50-100 kg liveweight) & $<0 \cdot 5$ \\
Breeders & $<0.1$
\end{tabular}

A Aflatoxin $\mathrm{BI}$ equivalent is derived from the ratios of acute toxicity in ducklings (Carnaghan et al. 1963) as: $1 \cdot 0 \mathrm{~B} 1+0 \cdot 2 \mathrm{~B} 2+0 \cdot 5 \mathrm{G} 1+0 \cdot 1 \mathrm{G} 2$.

Although sows and boars will probably tolerate $>0.5 \mathrm{mg} \mathrm{kg} \mathrm{kg}^{-1}$ in the feed for short periods, we suggest that these animals be fed diets containing not more than $0.1 \mathrm{mg} \mathrm{kg}^{-1}$, since they will be fed for longer periods.

Meat chickens are relatively tolerant of aflatoxins, the minimum known harmful feed concentration being $0.2 \mathrm{mg} \mathrm{kg}^{-1}$ (BI equivalent) (Reichmann et al. 1982) and this might suggest a good method of utilizing aflatoxin-containing feeds. However, our experience is that the fairly centralized Australian meat chicken industry is reluctant to use obviously mouldy grains because of fears of reduced palatability or toxicity. Aflatoxins are not common in Australian 
poultry feed. In 1971-88, 161 poultry feeds suspected of causing reduced production were assayed at this Institute. Aflatoxins were detected in 13 samples, mostly from peanut meal, and only 4 samples contained $>0.05 \mathrm{mg}$ aflatoxin Bl equivalent $\mathrm{kg}^{-1}$ (Blaney; unpublished data).

Factors mediating against widespread aflatoxicosis in northern Australia are the availability of feed grade wheat and barley and their usage as blends with maize and sorghum in intensive feeds, and the generally dry conditions occurring during grain harvest.

\section{Ochratoxin $A$}

At this Institute, ochratoxin A has been assayed routinely in more than 100 suspect animal feeds since 1980 (Blaney; unpubl. data). It was detected on six occasions in sorghum, maize or mouldy bread, but acute intoxication has not been confirmed. Ochratoxin $A$ has been found with aflatoxin in sorghum grain but at low concentrations of $0.001-0.1 \mathrm{mg} \mathrm{kg}^{-1}$ (Ketterer et al. 1982; Blaney; unpubl. data). However, concentrations of $2 \mathrm{mg} \mathrm{kg}^{-1}$ had only very mild effects on pigs in feeding trials (Tapia and Seawright 1984, 1985).

\section{Zearalenone and Trichothecenes}

Zearalenone is common in maize on the Atherton Tableland where it is associated with $F$. graminearum ear rot (Blaney et al. 1984b, 1986). Zearalenone also occurs in wheat infected with $F$. graminearum (Blaney et al. 1987; Blaney and Dodman 1988) and in sorghum which has sustained heavy rainfall during maturation and has then been stored without drying (Blaney 1984, 1985). A number of Fusarium spp. occur in sorghum and some high concentrations of zearalenone (up to $15 \mathrm{mg} \mathrm{kg}^{-1}$ ) were found in a few batches of sorghum grain in central Queensland following the floods in mid-1983. However, only trace levels were found in sorghum crops in 1984, when little weather-damage occurred (Blaney; unpubl. data).

Young female pigs are the most sensitive animals to the effects of zearalenone (Kuiper-Goodman et al. 1987). Concentrations of $1-5 \mathrm{mg} \mathrm{kg}^{-1}$ will induce pseudo-oestrus in about 4-7 days (Young et al. 1981; Blaney et al. 1984a; Williams et al. 1988). Concentrations of $5-20 \mathrm{mg} \mathrm{kg}-1$ may reduce fertility of sows and boars (Chang 1979). Up to $50 \mathrm{mg} \mathrm{kg}^{-1}$ has been fed to baconer-pigs in experiments in north America giving only slightly impaired growth and feed conversion (Smith 1980). Since surveys in Australia have shown that concentrations above $1 \mathrm{mg} \mathrm{kg}^{-1}$ in grains are very infrequent and only a few cases of intoxication have been recorded (Blaney et al. 1984a), the impact on animal production appears to be slight. However, trichothecenes and other Fusarium toxins are likely to be present in grain containing zearalenone. Deoxynivalenol occurs with zearalenone in wheat (Moore et al. 1985; Bryden et al. 1987), nivalenol occurs with zearalenone in maize (Blaney and Dodman 1988, and unpublished data) and other Fusarium toxins probably occur in mouldy sorghum (Williams et al. 1986). Fusarium species isolated from Australian weather-damaged sorghum have produced T-2 toxin and HT-2 toxin, deoxynivalenol and zearlenone in culture (Blaney, Dodman, Tyler and Moore; unpubl. data). 
Table 4. The effect on margin-over-feed-costs (MOFC) of reduced feed intakes by pigs growing from $20-50 \mathrm{~kg}$ caused by deoxynivalenol and the corresponding value of the wheat that restores the lost profits

\begin{tabular}{|c|c|c|c|c|c|}
\hline $\begin{array}{c}\text { Dietary } \\
\text { deoxynivalenol } \\
\left(\mathrm{mg} \mathrm{kg}^{-1}\right)\end{array}$ & $\begin{array}{l}\text { Daily feed } \\
\text { intake }^{A} \\
(\mathrm{~kg})\end{array}$ & $\begin{array}{l}\text { Feed } \\
\text { to } \\
\text { gain }^{\mathrm{A}}\end{array}$ & $\begin{array}{c}\text { Average } \\
\text { daily gain }{ }^{A} \\
(\mathrm{~kg})\end{array}$ & $\begin{array}{l}\text { MOFC }^{\mathrm{B}} \\
\left(\$ \text { sow }^{-1}\right. \\
\left.\text { year }^{-1}\right)\end{array}$ & $\begin{array}{c}\text { Grain } \\
\text { value }^{\mathrm{B}} \\
\left(\$ \text { tonne }^{-1}\right)\end{array}$ \\
\hline 0 & 2.05 & $2 \cdot 32$ & 0.89 & 870 & 155 \\
\hline 4 & $1 \cdot 76$ & $2 \cdot 22$ & 0.80 & 843 & 143 \\
\hline 8 & $1 \cdot 47$ & 2.63 & 0.58 & 806 & 126 \\
\hline 11 & $1 \cdot 28$ & $2 \cdot 94$ & 0.45 & 683 & 59 \\
\hline
\end{tabular}

A Pig performance results from Williams et al. (1988).

${ }^{B}$ Based on the cost of feed ingredients in southern Queensland, first quarter 1990. Profitability calculated on the basis that the experimental results applied for the period of growth from 20 to $50 \mathrm{~kg}$ live weight, but thereafter no difference occurred in performance until sale at $90 \mathrm{~kg}$ live weight. Calculations used cost-of-production 'what-if' computer models developed by the Queensland Department of Primary Industries.

The effect of deoxynivalenol on pigs is to reduce feed intake without affecting feed conversion except at $>8 \mathrm{mg} \mathrm{kg}^{-1}$. We have calculated that voluntary feed intake is depressed by $6 \%$ for each $1 \mathrm{mg} \mathrm{kg}^{-1}$ of dietary deoxynivalenol in the early stages of feeding, although some tolerance develops over time (Williams et al. 1988). Performance over the $20-50 \mathrm{~kg}$ period and the cost of this to a pig farmer can be seen in Table 4 .

Table 5. The responses of meat-chickens offered feed containing zearalenone ( $3 \mathrm{mg}$ $\mathrm{kg}^{-1}$ ) and 4-deoxynivalenol (12 $\mathrm{mg} \mathrm{kg}^{-1}$ ) from Fusarium graminearum-infected wheat (Mannion and Blaney 1988)

\begin{tabular}{lrr}
\hline \multicolumn{1}{c}{ Feed description } & Control & Mouldy \\
\hline Proportional consumption of mouldy and & $71 \%$ & $29 \%$ \\
$\quad$ control wheat diets offered as a choice & & \\
No choice situation, fed from 7-28 days & 56 & 51 \\
Daily feed intake (g) & $1 \cdot 73$ & $1 \cdot 78$ \\
Feed: gain & 33 & 29 \\
Average daily gain (g) & & \\
\hline
\end{tabular}

Poultry are more resistant to zearalenone and deoxynivalenol than pigs but reductions in feed intake may still occur at high concentrations (Mannion and Blaney 1988); this is shown in Table 5. Until more is known about the spectrum of mycotoxins commonly associated with zearalenone, and analytical methods are available, considerable caution must be exercised in feeding grain containing zearalenone. Farmers seeking to use the grain are advised to feed it either to ruminants as a supplement, to chickens at moderate concentrations, or to pigs at low concentrations and only in the finisher stage $(50-90 \mathrm{~kg}$ ).

In the final analysis, deoxynivalenol appears to be of very minor importance in Australia, with its known occurrence mainly around the N.S.W.-Queensland border ranges (Blaney et al. 1987; Tobin 1988).

Maize from the north Queensland tablelands can contain nivalenol and acetylnivalenol in addition to zearalenone. Some maize crops can contain at 
least $2 \mathrm{mg}$ zearalenone and $5 \mathrm{mg}$ nivalenol $\mathrm{kg}^{-1}$ at harvest (Blaney et al. $1984 \mathrm{~b}$, 1986, and unpubl. data), but the centralized drying and marketing system used in the region results in bulk maize with much less than this.

Maize screenings containing about $13 \mathrm{mg}$ nivalenol and $3 \mathrm{mg}$ zearalenone $\mathrm{kg}^{-1}$ were used in pig feeding trials (Williams and Blaney, unpubl. data). In an acute study of 2 weeks duration, $40 \mathrm{~kg}$ pigs were offered maize-based diets containing up to $8.9 \mathrm{mg}$ nivalenol and $1.5 \mathrm{mg}$ zearalenone $\mathrm{kg}^{-1}$. No vomiting occurred but voluntary feed intakes (VFI) were only half of those of pigs on control feed. Except for failure to cause vomiting, these results were similar to those we had obtained with equivalent concentrations of deoxynivalenol in wheat (Williams et al. 1988). However, in contrast to the deoxynivalenol results, a worsened feed conversion contributed to a greater impact on growth rate. These effects were subsequently confirmed in a pair-feeding study. Lower concentrations of nivalenol $\left(<3.6 \mathrm{mg} \mathrm{kg}^{-1}\right)$ appeared to be tolerated by the pigs without observable effects on performance.

Any effects of mycotoxins on the breeding herd would have severe economic consequences. Hence, the same maize was also fed to pregnant sows in two experiments to test the effects of nivalenol and zearalenone on fertility and reproductive performance. In the first study, sows were fed the mouldy maize from when pregnancy was confirmed at 30 days after mating until day 64 of pregnancy; performance was compared with that of a control group of sows. There was some feed refusal associated with feeding the mouldy maize but at slaughter we found no differences between the groups in either the number or weight of embryos or in conception rate (proportion of embryos to corpora lutea). In the second study, a comparison was made between control sows and those fed the mouldy maize either immediately from mating or after pregnancy was confirmed at 30 days after mating; in each case, feeding continued until the sows were slaughtered at approx. day 60 of pregnancy. Of 10 sows in each group, the number returning to service at 21 days was 1 , 2 and 3 respectively. As in the first study, reproductive performance was not affected by feeding the mouldy maize.

In summary, we consider that pigs are unlikely to be affected by the concentrations of nivalenol and zearalenone normally occurring in bulk maize on the Atherton Tableland. Screenings, or materials in which the mouldy kernels may be concentrated, would be better used as ruminant feed, which is the usual practice.

In the case of $F$. graminearum, the characteristic reddish-purple colour of maize kernels and the pinkish-red tips of wheat and triticale grains are useful indicators of the presence of zearalenone and trichothecenes (Blaney et al. 1986, 1987). Grain samples containing <1\% of such reddish grains are unlikely to contain sufficient $F$. graminearum mycotoxins to be of concern. These toxins cannot be detected in sorghum except by chemical assay. Dark, mouldy sorghum may contain Alternaria toxins if the damage occurred before harvesting (Williams et al. 1986), Fusarium toxins if very high moisture sorghum was stored in cool conditions (Blaney et al. 1984a) and Aspergillus toxins if high moisture sorghum was heated during storage (Ketterer et al. 1982). The presence of a strong musty smell is indicative of mould damage in storage. 
Table 6. The effects on pigs of feeds based on batches of $F$. moniliforme- and $D$. maydis-infected maize, purchased at different prices, and the margin-over-feed-cost (MOFC) of a piggery using the grain

\begin{tabular}{|c|c|c|c|c|}
\hline \multirow[t]{2}{*}{ Attribute } & \multicolumn{4}{|c|}{ Maize batch } \\
\hline & 1 & 2 & 3 & $4^{\mathrm{A}}$ \\
\hline Maize cost $\left(\$ \text { tonne }{ }^{-1}\right)^{B}$ & 160 & 135 & 110 & 110 \\
\hline Mouldy kernels (\%) & 4 & 17 & 21 & 15 \\
\hline $\begin{array}{l}\text { Daily feed intake, } 0-2 \text { weeks }{ }^{C} \\
\text { Feed conversion ratio, } 0-2 \text { weeks }^{c}\end{array}$ & $\begin{array}{l}1 \cdot 94 \\
2 \cdot 39\end{array}$ & $\begin{array}{l}1 \cdot 88 \\
2 \cdot 46\end{array}$ & $\begin{array}{l}1 \cdot 84 \\
2 \cdot 68\end{array}$ & $\begin{array}{l}1 \cdot 94 \\
2 \cdot 50\end{array}$ \\
\hline $\begin{array}{l}\text { Daily feed intake, } 0-5 \text { weeks }{ }^{C} \\
\text { Feed conversion ratio, } 0-5 \text { weeks } c\end{array}$ & $\begin{array}{l}2 \cdot 35 \\
2 \cdot 54\end{array}$ & $\begin{array}{l}2 \cdot 09 \\
2 \cdot 57\end{array}$ & $\begin{array}{l}2 \cdot 23 \\
2 \cdot 57\end{array}$ & $\begin{array}{l}2 \cdot 25 \\
2 \cdot 57\end{array}$ \\
\hline $\begin{array}{l}\text { MOFC }^{D} \\
\left(\$ \text { sow }^{-1} \text { year }^{-1}\right)\end{array}$ & 879 & 894 & 916 & 916 \\
\hline
\end{tabular}

A Batch 4 was heavily infected with both Diplodia maydis and $F$. moniliforme; other batches mainly with $F$. moniliforme.

${ }^{B}$ Costs in April 1987.

${ }^{C}$ Period of experimentation from a start live weight of $27.4 \mathrm{~kg}$; data from williams and Blaney (unpubl.)

D Profitability calculated as in Table 4.

\section{Fusarium moniliforme and Diplodia maydis Toxins}

F. moniliforme is the most prevalent Fusarium species in maize and sorghum in northern Australia but no cases of animal disease associated with it have been reported. Elsewhere, $F$. moniliforme causes leucoencephalomalacia in horses and the fungus has been linked to human diseases (Marasas 1982). Horses are not commonly fed large amounts of grain in northern Australia and no cases have been confirmed. Bryden et al. (1987) fed $F$. moniliforme-infected maize to pigs and chickens without apparent ill effects. We have tested the effect of using $F$. moniliforme-infected maize in pig feeds (Williams and Blaney; unpubl. data). Four batches of grain with $4-21 \%$ visually mouldy kernels were obtained from southern Queensland in 1985 and incorporated as the sole grain portion into pig feeds. The results are shown in Table 6 . In the first two weeks of experimentation from $27 \mathrm{~kg}$, there was some reduction in feed intake and worsened feed conversion efficiency in the batches with most damage, indicating some toxicity. However, over the full five weeks of experimentation, these effects diminished, indicating developing tolerance. As a consequence, profits increased by using the most damaged maize because of its lower purchase price.

Batch 4 (Table 6 ) was heavily infected with Diplodia maydis in addition to $F$. moniliforme. $D$. maydis caused one of the earliest recorded neuromycotoxicoses of ruminants, diplodiosis, in South Africa (Mitchell 1919). It has not been proven to occur elsewhere, but a similar syndrome was recroded in Queensland by Darvall (1964) in cattle grazing old maize cobs. D. maydis occurs in maize on the southern Darling Downs, between Toowoomba and Warwick. It used to occur on the Atherton Tableland, but has not been noted in recent years (Blaney et al. 1986). Maize heavily infected with $D$. maydis has been fed to cattle and chickens without apparent ill effects (Blaney et al. 1981). However, 
Australian isolates of $D$. maydis from this maize, when grown in culture, had a similar toxicity to chickens as isolates from Zimbabwe and South Africa (H. McFadden, personal communication).

Overall, $D$. maydis infestation does not appear to be sufficiently widespread to cause concern and the toxic effects, if any, should be compensated for by the lower price of such grain.

\section{Ustilago hordei Toxicity}

Covered smut in barley caused by this fungus is readily controlled by seed treatment but in most years some smutted barley becomes available as stock feed. We have fed barley from the Darling Downs, with $0.5 \%$ recoverable smut, to pigs and found it to be no different from clean barley (Williams et al. 1987). Smutted barley is also frequently used as cattle feed without apparent ill effects. However, there are some reports of the dusty mould causing reductions in palatability which can be overcome with molasses.

\section{Ergot Toxins}

Claviceps spp. are fungal parasites of grasses and cereal crops occurring in most parts of the world. They infect plants during flowering and replace the embryos with a hard purplish-black structure called a sclerotium or ergot body which is then harvested with the grain. C. purpurea is the most important, with a wide host range, and causing the gangrenous form of classical ergotism in animals. However, infection of cereal crops is usually insignificant in Australia. In 1986, dairy cattle in the Illawarra and Central Tablelands of N.S.W. suffered ergotism characterized by fever due to contamination of wheat, oats, barley and lupins with ryegrass seed infected with $C$. purpurea (Burgess et al. 1986). This was confirmed in feeding trials in cattle (Jang et al. 1987; Ross et al. 1989) and the material was also tested with chickens (Bakau and Bryden 1987). The disorder in cattle was reproduced with ergot levels of $0 \cdot 1-1 \%$, while in the chicken study, growth rate and feed conversion were impaired with a level of $0.5 \%$. In other countries, feeds containing more than $0.1 \%$ ergot have reduced feed intakes of growing pigs, but different batches containing up to $4 \%$ have been tolerated. Since ergot can cause agalactia, it should not be fed to late pregnant and lactating animals (Mantle 1978). No other cases of classical ergotism have been reported in Australia. However, $C$. paspali, the ergot of paspalum grasses, occasionally causes a convulsive form of ergotism in grazing animals (Connole and Johnston 1967; Noble 1985).

\section{Phomopsis Mycotoxins}

The main species of Phomopsis known as a mycotoxin producer is $P$. leptostromiformis, a pathogen and saprophyte of lupins. Several others are pathogens of soyabeans.

$P$. leptostromiformis causes lupinosis in sheep and cattle grazing lupin stubble in Western Australia (Gardiner 1967; Gardiner and Parr 1967). The structure of the principal mycotoxin phomopsin A has recently been clarified (Mackay et al. 1986) and surveys for phomopsin A in lupin seeds in Western Australia 
have been reported by Wood and Petterson (1986). Increased infection levels of lupin crops are associated with higher rainfall and cultivar susceptibility (Wood and Petterson 1985). Allen and Wood (1979) reported success in reducing the degree of infection of lupin stubbles and subsequent toxicity by hay-making. Since crude extracts of $P$. leptostromiformis were 30-50 times less toxic to pigs than sheep, pigs were considered to be at no risk of poisoning from infected lupin seed (Allen 1985).

$P$. phaseoli and $P$. longicolla are common in crops and seed of soybean in coastal districts of N.S.W. (Stovold and Francis 1987; G. E. Stovold, personal communication). These fungi regularly cause blight of stems and pods of mature plants and quality down-grading of harvested seed, particularly in seasons with wet autumns. They are not a problem in drier inland areas. $P$. phaseoli can cause liver damage in chickens due to unidentified toxins (Kung et al. 1977) and the fungus is known to produce cytochalasins (Cole et al. 1982). Australian $P$. longicolla isolates have also been shown to produce cytochalasins (Allen et al. 1989). There is obvious potential for mycotoxicosis in livestock fed infected soyabeans, but no clinical cases have been recorded to our knowledge.

\section{Sclerotinia sclerotiorium Toxicity}

In Queensland, $S$. sclerotiorum is an important disease agent of mung beans, soyabeans, navy beans, safflower and sunflower crops. The fungus invades the stalks and seeds, forming resting bodies or 'sclerotia' which are often harvested with the crop. These are difficult to remove, particularly in crops like sunflower where the sclerotia are of similar size to the seeds. S. sclerotiorum also causes 'pink rot' of celery, and many years ago (Scheel et al. 1963) it was recorded that celery pickers coming in contact with affected celery and exposed to sunlight developed a severe dermatitis due to psoralens. Mung bean screenings containing high concentrations of sclerotia were obtained from central Queensland and fed to pigs at the Biloela Research Station. No major depression in pig performance and no evidence of photosensitivity were observed (Williams and Daniels; unpubl. data).

\section{Pyrenofera tritici-repentis Toxicity}

P. tritici-repentis is common in Australian wheat (Klein 1987; Rees et al. 1988). It is evidenced by a pale, translucent pink colour extending over the entire grain which is otherwise plump and of normal colour. Such grains have been mistaken for Fusarium-infected grains. P. tritici-repentis is not known to produce mycotoxins and we have observed pigs to eat such wheat without apparent ill effect. However, controlled experiments have not yet verified the safety of this fungus.

\section{Alternaria alternata Toxins}

A. alternata is the most common fungus occurring in weather-damaged wheat and other grains in Australia (Southwell et al. 1980; Rees et al. 1984; Klein 1987). It is the main cause of the darkened tip of wheat known as 
'black point' and usually, though not always, it is the most common fungus in weathered sorghum. A. alternata produces the mycotoxins alternariol, alternariol mono-methyl ether, altenuene, altertoxin I and II and tenuazonic acid in laboratory culture. The chronic toxicity of the compounds is under investigation. Cultures of isolates of $A$. alternata are toxic to chickens in bioassay (Sauer et al. 1978; Griffin and Chu 1983), but the importance of these toxins in field-damaged grain is unclear (Bryden et al. 1984; Williams et al. 1986). Tenuazonic acid is far more toxic than alternariol and its methyl ether. Sauer et al. (1978) reported that only isolates of $A$. alternata that produced tenuazonic acid were lethal to chicken embryos. There have been no surveys for tenuazonic acid or altertoxins in bulk grains in Australia, but alternariol and its methyl ether have been detected in sorghum at concentrations up to $10 \mathrm{mg} \mathrm{kg}^{-1}$ (Bryden et al. 1984; Williams et al. 1986).

\section{Toxins of Weather-damaged Sorghum}

Sorghum grain is particularly prone to mould invasion, since wet weather often occurs during grain maturation (February-April in Queensland). In 1983, sorghum crops suffered severe damage from heavy rainfall and flooding (Blaney 1985). Similar problems occur in most countries where sorghum is grown. A wide range of fungi can be isolated, most potentially toxigenic. Some of the more prevalent are A. alternata, Curvularia spp., Phoma spp. and Fusarium spp. Toxins commonly found in damaged sorghum are alternariols and zearalenone. Traces of aflatoxins and ochratoxin $\mathrm{A}$ are sometimes found in Queensland and can greatly increase in sorghum stored wet after harvest, despite the low frequency of Aspergillus spp.

Table 7. Responses of meat-chickens (from 1-35 days of age) fed diets based on weathered, mouldy sorghum, 1983 (Bryden et al. 1984)

\begin{tabular}{llcc}
\hline & Control & Mouldy A & Mouldy B \\
\hline Alternariol $\left(\mathrm{mg} \mathrm{kg}^{-1}\right)$ & 0 & 10 & $7 \cdot 2$ \\
Alt. methyl ether $\left(\mathrm{mg} \mathrm{kg}^{-1}\right)$ & 0 & $3 \cdot 6$ & $7 \cdot 2$ \\
Feed conversion ratio & $1 \cdot 94$ & $2 \cdot 05$ & $2 \cdot 12$ \\
Daily weight gain (g) & 37 & 32 & 35 \\
Liver weight 35 days (g) & 28 & 39 & 34 \\
\hline
\end{tabular}

Table 8. Responses of pigs (23-81 kg liveweight) fed diets based on weathered, mouldy sorghum from central Queensland, 1983 (Williams et al. 1986)

\begin{tabular}{lcccc}
\hline & Control & Mouldy A & Mouldy B & Mouldy C \\
\hline Alternariol $\left(\mathrm{mg} \mathrm{kg}^{-1}\right.$ ) & $<0 \cdot 1$ & $6 \cdot 2$ & $10 \cdot 8$ & $10 \cdot 8$ \\
Alt. methyl ether $\left(\mathrm{mg} \mathrm{kg}^{-1}\right)$ & $<0 \cdot 1$ & $1 \cdot 6$ & $5 \cdot 0$ & $5 \cdot 4$ \\
Zearalenone $\left(\mathrm{mg} \mathrm{kg}^{-1}\right)$ & $<0 \cdot 01$ & 0.20 & $0 \cdot 09$ & $1 \cdot 26$ \\
Feed conversion ratio & $2 \cdot 68$ & $2 \cdot 83$ & $2 \cdot 77$ & 3.06 \\
Daily weight gain (g) & 652 & 612 & 628 & 547 \\
\hline
\end{tabular}


Table 9. Strategy for the effective use of moulded feed and comments on the toxicity of mycotoxins known to occur in Australian grains

\begin{tabular}{|c|c|}
\hline Condition & Comments on toxicity and strategies for using moulded feed \\
\hline Moulded feed & $\begin{array}{l}\text { Representative samples should be taken for nutrient, mycological and/or } \\
\text { mycotoxin analysis to best assess feeding options. } \\
\text { Obviously mouldy and caked feed should be discarded (having regard to } \\
\text { human exposure) and remaining feed well mixed and dried before being } \\
\text { fed. } \\
\text { Damaged feed should be used at low inclusion levels initially and preferably } \\
\text { to non-breeding older animals. } \\
\text { Fish, ducklings and turkeys are often the most susceptible; pigs, calves } \\
\text { and chickens are intermediate and adult ruminants are usually the most } \\
\text { tolerant. } \\
\text { The effect of 'off' aromas and flavours may be lessened with sweeteners } \\
\text { such as molasses while alumino-silicate clays such as bentonite and zeolite } \\
\text { may be of some benefit. } \\
\text { Moulded feed should not be fed to animals within } 2 \text { weeks of slaughter } \\
\text { to reduce the risk of carcase residues. }\end{array}$ \\
\hline Aflatoxins ${ }^{B}$ & $\begin{array}{l}\text { Primary liver toxins which are expressed usually as a chronic debilitat- } \\
\text { ing disease, although acute toxicity with high mortalities has occurred; } \\
\text { carcinogenic and teratogenic. } \\
\text { Aflatoxin } \mathrm{Bl} \text { equivalent concentration in feed should not exceed } 0.02 \text {, } \\
0.1,0.2 \text { and } 0.5 \mathrm{mg} \mathrm{kg}^{-1} \text { for weaner pigs, grower and breeder pigs, } \\
\text { meat chickens and finisher pigs respectively; cattle appear able to tolerate } \\
\text { concentrations up to } 0.7 \mathrm{mg} \mathrm{kg} \text {. }\end{array}$ \\
\hline Alternariols $\mathrm{C}$ & $\begin{array}{l}\text { Domestic livestock and birds are quite tolerant of alternariol and its methyl } \\
\text { ether. } \\
\text { Alternaria isolates overseas have produced tenuazonic acid, altertoxins and } \\
\text { altenuene which are potent inhibitors of protein synthesis; these toxins } \\
\text { have not been surveyed in Australia. }\end{array}$ \\
\hline Deoxynivalenol $^{\mathrm{D}}$ & $\begin{array}{l}\text { Toxicosis is characterized by marked inappetence and, in pigs, vomiting } \\
\text { can occur at high doses. } \\
\text { Pigs are most susceptible with feed intake of growers being reduced by } \\
\text { about } 6 \% \text { for each } 1 \mathrm{mg} \mathrm{kg}^{-1} \text { dietary deoxynivalenol. } \\
\text { Seldom occurs in Australia at concentrations likely to cause obvious toxicity. }\end{array}$ \\
\hline Nivalenol $^{\mathrm{E}}$ & $\begin{array}{l}\text { Causes a similar effect as deoxynivalenol except that vomiting is not a } \\
\text { feature. } \\
\text { Common in maize from north Queensland, but concentrations are usually } \\
\text { too low to be toxic to pigs; maize screenings more likely to be toxic. } \\
\text { Abortifacient in mice but similar effects in pregnant sows have not been } \\
\text { observed. }\end{array}$ \\
\hline Ochratoxin $\mathrm{A}^{\mathrm{F}}$ & $\begin{array}{l}\text { A liver and kidney toxin more likely to occur as a chronic rather than } \\
\text { acute toxicity; teratogenic in mice. } \\
\text { Pigs are particularly susceptible, while adult ruminants are very tolerant. } \\
\text { More likely to be a problem in cooler-wet climates. }\end{array}$ \\
\hline Zearalenone & $\begin{array}{l}\text { A pseudo-oestrogenic mycotoxin that is frequently encountered in Fusarium- } \\
\text { infected grain crops. } \\
\text { Concentrations up to } 15 \mathrm{mg}, \mathrm{kg}^{-1} \text { have occurred in very mouldy sorghum } \\
\text { but } 0 \cdot 5-2 \mathrm{mg} \mathrm{kg}^{-1} \text { are more typical in grain. } \\
\text { Young female pigs are the most sensitive animal species with dietary } \\
\text { concentrations as little as } 0 \cdot 5-1 \mathrm{mg} \mathrm{kg}^{-1} \text { likely to cause pseudo-oestrus; } \\
\text { vaginal and rectal prolapses can occur at sufficient doses. } \\
\text { Reduced fertility of sows and boars is unlikely to occur with dietary } \\
\text { concentration less than } 5 \mathrm{mg} \mathrm{kg}^{-1} \text {. }\end{array}$ \\
\hline
\end{tabular}

A Carson and Smith (1983); Harvey et al. (1988). B Austwick (1978); Keyl (1978). C Cole and Cox (1981); Carlton and Szczech (1978). D Williams et al. (1988). E Sato and Ueno (1977). F Cole and Cox (1981); Ribelin (1978); Krogh (1978). 
Bryden et al. (1984) fed two batches of mouldy, weather-damaged sorghum (1983 harvest) to meat chickens and found evidence of toxicity, since liver, spleen and pancreas weights were increased relative to controls. Some of their results are shown in Table 7 . They ascribed the toxicity to Alternaria mycotoxins but this hypothesis remains unproven until specific purified mycotoxins can be shown to produce similar results to the mouldy sorghum. Williams et al. (1986) fed different batches of 1983 mouldy sorghum to pigs and also demonstrated some toxicity (Table 8 ). However, since both alternariols and zearalenone were detected, Williams et al. (1986) considered it equally likely that the toxicity was due to Alternaria mycotoxins such as tenuazonic acid or Fusarium mycotoxins other than zearalenone.

Both groups of researchers demonstrated impaired feed conversion ratios of up to $14 \%$ and we estimate the economic consequences of this, using cost of production 'what if' computer models, as reducing the value of the grain by at least $20 \%$ in pigs and $50 \%$ in meat chickens. However, in these experiments, the sorghum was very mouldy and was the sole grain component of the feeds. Use of less mouldy sorghum and its dilution in the feed should allow such grain to be effectively used if a satisfactory price reduction is available.

\section{Conclusions}

Animal industries have much to gain from the effective use of mouldy grains but there are risks, not just because of the possible presence of mycotoxins, but also because of effects on nutritional value and palatability caused by moulds. Only a thorough evaluation of all these factors in the light of the desired use of the grain will optimize results, and the skills of the chemist and nutritionist are both vital to this study. A summary of strategies for the effective use of moulded feed and comments on the toxicity of mycotoxins likely to occur in grains is given in Table 9.

In this review, we have shown that many mycotoxins occur in Australia, but that they seldom cause serious losses to animal production. Our climate and patterns of crop production are constantly changing and seasonal influences have the potential to increase greatly the current extent of mycotoxin contamination. Much remains unknown about the long-term effects of mycotoxin ingestion in humans, and mycotoxin standards for human foods are likely to become increasingly stringent.

\section{Acknowledgments}

Financial support received from the Australian Pig Research Council is gratefully acknowledged.

\section{References}

Adret-Hausberger, M., and Cumming, R. B. (1985). Behavioural aspects of food selection in young chickens. In 'Recent Advances in Animal Nutrition in Australia in 1985'. (Ed. R. B. Cumming.) Paper 18. (Univ. of New England Publishing Unit: Armidale.)

Allcroft, R. (1969). Aflatoxicosis in farm animals. In 'Aflatoxin: Scientific Background, Control and Implications'. (Ed. L. A. Goldblatt.) pp. 237-64. (Academic Press: New York.)

Allen, J. G. (1985). The toxicity of phomopsin in a crude extract of Phomopsis leptostromiformis to sheep and pigs. In 'Plant Toxicology'. (Eds A. A. Seawright et al.) pp. 596-603. (Queensland Poisonous Plants Committee: Brisbane.) 
Allen, J. G., Stovold, G. E., Blaney, B. J., Smith, H. J. P., Shaw, T. J., and Tyler, A. L. (1989). The toxicogenicity of isolates of Phomopsis and Diaporthe spp. obtained from soybean plants and the apparent production of cytochalasans by Phomopsis longicolla. Proc. 3rd Int. Symp. on Poison Plants. July 1989, Logan, Utah. (in press.)

Allen, J. G., and Wood, P. McR. (1979). The prevention of lupinosis by making lupin hay. Aust. Vet. J. 58, 38-9.

Austwick, P. K. C. (1978). Aflatoxicosis in poultry. In 'Mycotoxic Fungi, Mycotoxins, Mycotoxicoses: An Encyclopedic Handbook Vol. 2'. (Eds T. D. Wyllie and L. G. Morehouse.) pp. 279-301. (Marcel Dekker: New York.)

Baidoo, S. K., and Aherne, F. X. (1986). Effect of flavour additives on utilisation of canola meal by young pigs. In '65th Alberta Annual Feeders' Day Report'. pp. 104-6. (University of Alberta: Alberta.)

Bakau, B. J. K., and Bryden, W. L. (1987). Toxicity of ergots of Clavicepts purpurea in chickens subjected to heat stress. Proc. Nutr. Soc. Aust. 12, 170.

Baldwin, B. A. (1976). Quantitative studies on taste preference in pigs. Proc. Nutr. Soc. 35 , 69-73.

Bartov, I. (1983). Effects of propionic acid and of copper sulphate on the nutritional value of diets containing mouldy corn for broiler chicks. Poult. Sci. 62, 2195-200.

Bartov, I., Paster, N., and Lisker, N. (1982). The nutritional value of mouldy grains for broiler chicks. Poult. Sci. 61, 2247-54.

Batterham, E. S., Lewis, C. E., Lowe, R. F., and McMillan, C. J. (1980). Digestible energy content of cereals and wheat by-products for growing pigs. Anim. Prod. 31, 259-71.

Blaney, B. J. (1981). Aflatoxin survey of maize from the 1978 crop in the South Burnett region of Queensland. Qld J. Agric. Anim. Sci. 38, 7-12.

Blaney, B. J. (1984). Mycotoxins in crops: epidemiological aspects in Queensland. In 'Plant Toxicology'. (Eds A. Seawright et al.) pp. 578-88. (Queensland Poisonous Plants Committee: Brisbane.)

Blaney, B. J. (1985). Mycotoxins in crops grown in different climatic regions of Queensland. In 'Trichothecenes and Other Mycotoxins.' (Ed. J. Lacey.) pp. 97-108. (John Wiley: Chichester.)

Blaney, B. J. (1986). Mycotoxins in water-damaged and mouldy wheat from temporary bulk stores in Queensland. Aust. J. Agric. Res. 37, 561-5.

Blaney, B. J., Bloomfield, R. C., and Moore, C. J. (1984a). Zearalenone intoxication of pigs. Aust. Vet. J. 61, 24-7.

Blaney, B. J., and Dodman, R. L. (1988). Produciton of the mycotoxins zearalenone, 4deoxynivalenol and nivalenol by isolates of Fusarium graminearum Groups 1 and 2 from cereals in Queensland. Aust. J. Agric. Res. 39, 21-9.

Blaney, B. J., Kelly, M. A., Tyler, A. L., and Connole, M. D. (1989). Aflatoxin and cyclopiazonic acid production by Queensland isolates of Aspergillus flavus and Aspergillus parasiticus. Aust. J. Agric. Res. 40, 395-400.

Blaney, B. J., Mannion, P. F., Tudor, G. D., and McKenzie, R. A. (1981). Examination of Diplodia maydis infected maize for toxicity to chickens and cattle. Aust. Vet. J. 57, 196.

Blaney, B. J., Moore, C. J., and Tyler, A. L. (1984b). Mycotoxins and fungal damage in maize harvested during 1982 in far north Queensland. Aust. J. Agric. Res. 35, 463-71.

Blaney, B. J., Moore, C. J., and Tyler, A. L. (1987). The mycotoxins-4-deoxynivalenol, zearalenone and aflatoxin in weather-damaged wheat harvested 1983-85 in south-eastern Queensland. Aust. J. Agric. Res. 38, 993-1000.

Blaney, B. J., Ramsey, M. D., and Tyler, A. L. (1986). Mycotoxins and toxigenic fungi in insect-damaged maize harvested during 1983 in far north Queensland. Aust. J. Agric. Res. 37, 235-44.

Bryden, W. L., Lloyd, A. B., and Cumming, R. B. (1980). Aflatoxin contamination of Australian animal feeds and suspected cases of mycotoxicosis. Aust. Vet. J. 56, 176-80.

Bryden, W. L., Love, R. J., and Burgess, L. W. (1987). Feeding grain contaminated with Fusarium graminearum and Fusarium moniliforme to pigs and chickens. Aust. Vet. $J .64,225-6$.

Bryden, W. L., Rajion, M. A., Lloyd, A. B., and Cumming, R. B. (1975). Surveys of Australian feedstuffs for toxigenic strains of Aspergillus flavus and for aflatoxin. Aust. Vet. J. 51, 491-3.

Bryden, W. L., Suter, D. A. I., and Jackson, C. A. W. (1984). Response of chickens to sorghum contaminated with Alternaria. Proc. Nutr. Soc. Aust. 9, 109. 
Burgess, L. W., Bryden, W. L., Jessup, T. M., Scrivener, C. J., and Barrow, K. D. (1986). Role for ergot alkaloids in bovine hyperthermia. Proc. Nutr. Soc. Aust. 11, 120.

Carlton, W. W., and Szczech, G. M. (1978). Mycotoxicoses in laboratory animals. In 'Mycotoxic Fungi, Mycotoxins, Mycotoxicoses: An Encyciopedic Handbook Vol. 2'. (Eds T. D. Wyllie and L. G. Morehouse.) pp. 373-406. (Marcel Dekker: New York.)

Carnaghan, R. B. A., Hartley, D., and O'Kelly, J. (1963). Toxicity and fluorescence properties of the aflatoxins. Nature, London 200, 1101.

Carson, M. S., and Smith, T. K. (1983). Role of bentonite in prevention of T2 toxicosis in rats. J. Anim. Sci. 57, 1499-505.

Castor, L. L., and Frederiksen, R. A. (1981). Grain deterioration in sorghum. In 'Proc. Int. Symp. on Sorghum Grain Quality, 28-31 October, 1981'. pp. 163-9. (ICRISAT: Patancheru, India.)

Chang, K. (1979). Effects of the mycotoxin zearalenone on swine reproduction. Am. J. Vet. Res. 40, 1260-7.

Christensen, C. M., and Kaufman, H. H. (1965). Deterioration of stored grain by fungi. Ann. Rev. Phytopathol. 3, 69-84.

Cole, R. J., and Cox, R. H. (1981). In 'Handbook of Toxic Fungal Metabolites'. pp. 615-45. (Academic Press: New York.)

Cole, R. J., Wilson, D. M., Harper, J. L., Cox, R. H., Cochran, T. W., Cutler, H. G., and Bell, D. K. (1982). Isolation and identification of two new (II) cytochalasins from Phomopsis sojae. J. Agric. Food Chem. 30, 301-4.

Connole, M. D., Blaney, B. J., and McEwan, T. (1981). Mycotoxins in animal feeds and toxic fungi in Queensland 1971-80. Aust. Vet. J. 57, 314-8.

Connole, M. D., and Johnston, L. A. Y. (1967). A review of animal mycoses in Australia. Vet. Bull. (Weybridge) 37, 145-53.

Connor, J. K., Hurwood, I. S., Burton, H. W., and Fuelling, D. E. (1969). Some nutritional aspects of feeding sorghum grain of high tannin content to growing chickens. Aust. J. Exp. Agric. Anim. Husb. 9, 497-501.

Darvall, P. M. (1964). Mouldy corn cobs, a danger to cows. Qld Agric. J. 90, 692-4.

Davidson, S. (1984). Shot, sprung and down graded. Rural Res. in CSIRO 123, 4-7.

Deyoe, C. W., and Shellenberger, J. A. (1965). Amino acids and proteins in sorghum grain. J. Agric. Food Chem. 13, 446-50.

Eggum, B. O. (1977). The nutritive quality of cereals. Cereal Res. Commun. 5, 153-7.

Erickson, J. (1988). Lupines: a potential source of protein for swine. Feedstuffs 60, 18.

Forsyth, D. M., Yoshizawa, T., Morvoha, N., and Tuite, J. (1977). Emetic and refusal activity of deoxynivalenol to swine. Appl. Environ. Microbiol. 34, 547-52.

Francis, B. J., and Wood, J. F. (1982). Changes in the nutritive content and value of feed concentrates during storage. In 'Handbook of Nutritive Value of Processed Food-Volume II, Animal Feeds'. (Ed. M. Rechciyl Jr.) pp. 161-89. (CRC Press: Boca Raton, Florida.)

Gardiner, M. R. (1967). Lupinosis. Adv. Vet. Sci. 11, 85-138.

Gardiner, M. R., and Nairn, M. (1962). Facial eczema in West Australian sheep. J. Agric. West. Aust. 3, 85-92.

Gardiner, M. R., and Parr, W. H. (1967). Pathogenesis of acute lupinosis of sheep. J. Comp. Pathol. Ther. 77, 51-62.

Grammer, J. C., McGinnis, J., and Pubols, M. H. (1983). The rachitogenic effects of fractions of rye and certain polysaccharides. Poult. Sci. 62, 103-9.

Green, P. E., Blaney, B. J., Moore, C. J., and Connole, M. D. (1989). Identification and preliminary evaluation of viriditoxin, a metabolite of Paecilomyces varioti, as an insecticide for sheep blowfly, Lucilla cuprina (Wied.). Gen. Appl. Ent. 21, 33-7.

Griffin, G. F., and Chu, F. S. (1983). Toxicity of the Alternaria metabolites alternariol, alternariol monomethyl ether, altenuene and tenuazonic acid in the chicken embryo assay. Appl. Environ. Microbiol. 46, 1420-2.

Griffiths, D. W. (1989). Polyphenolics and their possible effect on nutritive value. Aspects Appl. Biol. 19, 93-103.

Harvey, R. E., Kubena, L. F., Phillips, T. D., Huff, W. E., and Corrier, D. E. (1988). Approaches to the prevention of aflatoxicosis explored. Feedstuffs 60, 11-2.

Hocking, A. D., Holds, K., and Tobin, N. F. (1988). Intoxication by tremorgenic mycotoxin (peritem A) in a dog. Aust. Vet. J. 65, 82-5. 
Jang, I. H., van der Tol, J., Bryden, W. L., McDowell, G. H., Ross, A. D., Christie, B. M., and Burgess, L. W. (1987). Ergotism in dairy cattle-effects of ingestion of ergots from Claviceps purpurea. Proc. Nutr. Soc. Aust. 12, 169.

Ketterer, P. J., Blaney, B. J., Moore, C. J., McInnes, I. S., and Cook, P. W. (1982). Field cases of aflatoxicosis in pigs. Aust. Vet. J. 59, 113-7.

Keyl, A. C. (1978). Aflatoxicosis in cattle. In 'Mycotoxic Fungi, Mycotoxins, Mycotoxicoses: An Encyclopedic Handbook Vol. 2'. (Eds T. D. Wyllie and L. G. Morehouse.) pp. 9-28. (Marcel Dekker: New York.)

Klein, T. A. (1987). Fungi associated with discoloured wheat grain in northern New South Wales. Australas. Plant Path. 16, 69-71.

Krogh, P. (1978). Mycotoxic nephropathy in swine. In 'Mycotoxic Fungi, Mycotoxins, Mycotoxicoses: An Encyclopedic Handbook Vol. 2'. (Eds T. D. Wyllie and L. G. Morehouse.) pp. 236-56. (Marcel Dekker: New York.)

Kuiper-Goodman, T., Scott, P. M., and Watanabe, H. (1987). Risk assessment of the mycotoxin zearalenone. Regul. Toxicol. Pharmacol. 7, 253-306.

Kung, H. C., Chipley, J. R., Latshaw, J. D., Kerr, K. M., and Wilson, R. F. (1977). Chronic mycotoxicosis in chicks caused by toxins from Phomopsis grown on soybeans. $J$. Comp. Path. 87, 325-33.

McDermott, E. B., and Pace, J. (1960). Comparison of the amino acid composition of the protein in flour and endosperm from different types of wheat, with particular reference to variation in lysine content. J. Sci. Food Agric. 11, 109-15.

Mackay, M. F., van Donkelaar, A., and Culvenor, C. C. J. (1986). The X-ray structure of phomopsin A, a hexapeptide mycotoxin. J. Chem. Soc. Chem. Commun. 1219-21.

McKenzie, R. A., Blaney, B. J., Connole, M. D., and Fitzpatrick, L. A. (1981). Acute aflatoxicosis in calves fed peanut hay. Aust. Vet. J. 57, 284-6.

Mangan, J. L. (1988). Nutritional effects of tannins in animal feeds. Nutr. Res. Rev. 1, 209-231.

Mannion, P. F., and Blaney, B. J. (1988). Responses of meat chickens offered 4-deoxynivalenol and zearalenone-containing wheat, naturally infected with Fusarium graminearum. Aust. J. Agric. Res. 39, 533-40.

Mannion, P. F., Blaney, B. J., and Levitt, M. S. (1987). The nutritional value for meat chickens of water-damaged wheat from temporary bulk stores in Queensland. Aust. J. Agric. Res. 38, 621-8.

Mantle, P. G. (1978). Ergotism in swine. In 'Mycotoxic Fungi, Mycotoxins, Mycotoxicoses: An Encyclopedic Handbook Vol. I'. (Eds T. D. Wyllie and L. G. Morehouse.) pp. 273-5. (Markel Dekker: New York.)

Marasas, W. F. O. (1982). Mycotoxicological investigations on corn produced in esophageal cancer areas in Transkei. In 'Cancer of the Esophagus, Vol. 1'. (Ed. C. J. Pfeiffer.) pp. 29-40. (CRC Press: Boca Raton.)

Mitchell, D. T. (1919). Poisoning of cattle by Diplodia-infected maize. S. Afr. J. Sci. 16, 446-52.

Moir, K. W., and Connor, J. K. (1977). A comparison of three fibre methods for predicting the metabolizable energy content of sorghum grain for poultry. Anim. Food Sci. Technol. 2, 197-203.

Moore, C. J., Blaney, B. J., Spencer, R. A., and Dodman, R. L. (1985). Rejection by pigs of mouldy grain containing deoxynivalenol. Aust. Vet. J. 62, 60-2.

Noble, J. W. (1985). Suspected poisoning of cattle by Claviceps spp. on water couch. Aust. Vet. J. 62, 432-3.

Peer, D. J., and Leeson, S. (1985a). Nutrient content of hydroponically sprouted barley. Anim. Food Sci. Technol. 13, 191-202.

Peer, D. J., and Leeson, S. $(1985 \mathrm{~b})$. Feeding value of hydroponically sprouted barley for poultry and pigs. Anim. Food Sci. Technol. 13, 183-90.

Rees, R. G., Martin, D. J., and Law, D. P. (1984). Black point in bread wheat: effects on quality and germination, and fungal associations. Aust. J. Exp. Agric. Anim. Husb. 24, 601-5.

Rees, R. G., Platz, G. J., and Mayer, R. J. (1988). Susceptibility of Australian wheats to Pyrenofera tritici-repentis. Aust. J. Agric. Res. 39, 141-51.

Reichmann, K. G., Blaney, B. J., Connor, J. K., and Runge, B. M. (1982). The significance of aflatoxin and ochratoxin in the diet of Australian chickens. Aust. Vet. J. 58, 211-12.

Ribelin, W. E. (1978). Ochratoxicosis in cattle. In 'Mycotoxic Fungi, Mycotoxins, Mycotoxicoses: An Encyclopedic Handbook Vol. 2'. (Eds T. D. Wyllie and L. G. Morehouse.) pp. 28-36. (Marcel Dekker: New York.) 
Rogers, L. J. (1985). Effect of brain asymmetry on learning and feeding in chickens. In 'Recent Advances in Animal Nutrition in Australia'. (Ed. R. B. Cumming.) Paper 20. (University of New England Publishing Unit: Armidale.)

Ross, A. D., Bryden, W. L., Bakau, W., and Burgess, L. W. (1989). Induction of heat stress in beef cattle by feeding the ergots of claviceps purpurea. Aust. Vet. J. 66, 247-9.

Salmon, R. E., and O'Neil, J. B. (1977). Effects of frost damage on physical and chemical characteristics and true metabolizable energy of wheat. Can. J. Anim. Sci. 57, 755-60.

Sato, N., and Ueno, Y. (1977). Comparative toxicities of trichothecenes. In 'Mycotoxins in Human and Animal Health'. (Eds J. V. Rodricks et al.) pp. 295-307. (Pathotox Publishers: Park. Forest South.)

Sauer, D. B., Seitz, L. M., Burroughs, R., Mohr, H. E., West, J. L., Milleret, R. J., and Anthony, H. D. (1978). Toxicity of Alternaria metabolites found in weathered sorghum grain at harvest. J. Agric. Food Chem. 26, 1380-3.

Scheel, L. D., Perone, V. B., Larkin, R. L., and Kupal, R. E. (1963). The isolation and characterisation of two phototoxic furanocoumarins (psoralens) from diseased celery. Biochemistry 2, 1127-31.

Smith, T. K. (1980). Influence of dietary fibre, protein and zeolite on zearalenone toxicosis in rats and swine. J. Anim. Sci. 50, 278-85.

Southwell, R. J., Brown, J. F., and Wong, P. T. W. (1980). Effect of inoculum density, stage of plant growth and dew period on the incidence of black point caused by Alternaria alternata in durum wheat. Ann. Appl. Biol. 96, 29-35.

Stovold, G. E., and Francis, A. (1987). Incidence of Phomopsis phaseoli (Desm.) Sacc. in crops and seed of soybean in New South Wales. Aust. J. Exp. Agric. 27, 317-21.

Tapia, M. O., and Seawright, A. A. (1984). Experimental ochratoxicosis A in pigs. Aust. Vet. J. 61, 219-22.

Tapia, M. O., and Seawright, A. A. (1985). Experimental combined aflatoxin B1 and ochratoxin A intoxication in pigs. Aust. Vet. J. 62, 33-7.

Taverner, M. R., and Farrell, D. J. (1981). Availability to pigs of amino acids in cereal grains. 4. Factors influencing the availability of amino acids and energy in grains. Br. J. Nutr. 46, 181-92.

Taverner, M. R., Rayner, C. J., and Biden, R. S. (1975). Amino acid content and digestible energy value of sprouted, rust-affected and sound wheat in pig diets. Aust. J. Agric. Res. 26, 1109-13.

Tobin, N. F. (1988). Presence of deoxynivalenol in Australian wheat and triticale--New South Wales Northern Rivers Region, 1983. Aust. J. Exp. Agric. 28, 107-10.

Walsh, A. D. (1966). Facial eczema of sheep in Victoria. J. Agric. Vic. Dept Agric. 64, 519-22.

Williams, K. C., Blaney, B. J., and Magee, M. H. (1988). Responses of pigs fed wheat naturally infected with Fusarium graminearum and containing the mycotoxins 4-deoxynivalenol and zearalenone. Aust. J. Agric. Res. 39, 1095-105.

Williams, K. C., Blaney, B. J., and Peters, R. T. (1986). Nutritive value of weather-damaged sorghum grain for pigs. Proc. Aust. Soc. Anim. Prod. 16, 395-8.

Williams, K. C., Blaney, B. J., and Peters, R. T. (1987). Nutritive value of smut-affected barley for pigs. In 'Manipulating Pig Production'. (Eds J. L. Barnett et al.) p. 138. (Australasian Pig Science Association: Animal Research Institute, Werribee.)

Williams, K. C., and Daniels, L. J. (1985). The tolerance of pigs to the contamination of grain with seeds of Sesbabia cannabina. In 'Plant Toxicology'. (Eds A. Seawright et al.) pp. 157-64. (Queensland Poisonous Plants Committee: Brisbane.)

Williams, K. C., and McIntosh, B. (1986). Pig feeds-nutrient composition. Agdex 440/60, F38 May 86. Queensland Department of Primary Industries, Brisbane.

Wood, P. MCR., and Petterson, D. S. (1985). A survey of Phomopsis leptostromiformis infection of lupin seed in Western Australia: 1976-81. Aust. J. Exp. Agric. 25, 164-8.

Wood, P. McR., and Petterson, D. S. (1986). Phomopsis leptostromiformis infection and phomopsin A content of lupin seed in Western Australia. Aust. J. Exp. Agric. 26, 583-6.

Young, L. G., Vesonder, R. F., Funnell, H. S., Simons, I., and Wilcock, B. (1981). Mouldy corn in diets of swine. J. Anim. Sci. 52, 1312-18. 